\title{
EVALUATION OF GROWING AND FLOWERING OF FIVE SPECIES OF ORNAMENTAL GRASSES IN THE REGION OF LUBLIN
}

\author{
Krystyna Pudelska \\ Institute of Ornamental Plants and Landscape Architecture, University of Life Sciences in Lublin, Leszczyńskiego 58, 20-068 Lublin \\ e-mail: kpudelska@autograf.pl
}

Received: 3.10 .2008

\section{S u m m a r y}

The great decorative diversity (shape and size of inflorescences, colouring and texture of leaves, varied intensity of growth) as well as big tolerance to habitat conditions, relatively small susceptibility to diseases and small sensitivity to 'ornamental grasses' pests favour their popularization in different gardens and urban areas. The examined species all may be recommended to plant in cooler east regions of Poland. Species which begin the earliest vegetation and flowering were Calamagrostis $\mathrm{x}$ acutiflora 'Karl Foerster' and Deschamsia caespitosa 'Goldtau'. These species, best planted separately or in small groups, can be also recommended in small garden compositions. For large areas, naturalistic gardens as well as structural plants of flowerbeds the best are Calamagrostis x acutiflora 'Karl Foerster', Deschampsia caespitosa 'Goldtau' and Miscanthus sacchariflorus 'Robusta'. Phalaris arundinacea L. is a typical ground covering grass with decorative leaves.

Key words: ornamental grasses; Calamagrostis, Deschampsia, Miscanthus, Muchlenbergia, Phalaris; growth flowering

\section{INTRODUCTION}

Perennials are a popular decorative component of gardens. Apart from the best known genera as Peonia, Phlox or Aster, plants until recently forgotten and less known are regaining their popularity. They include 'ornamental grasses', also called 'bedflowers'. Nowadays, they are being gradually introduced into gardens and other green areas. It is an interesting group of plants due to their characteristic architecture, varied shape of inflorescences as well as colours and texture of leaves ( $\mathrm{Ur}$ b a ń s k i , 2001). Thanks to their lightness and susceptibility to the smallest move of the air, they bring a new dynamic element to garden compositions. Grasses come from different parts of the world so that they grow in a great variety of habitats (M i z i a n ty, 1995; F r e y, 1997) thus it is possible to choose plenty of species and varieties which are suitable for water gardens, poor sites or urban areas (F a l k ow s k i, 1982; H a b e r, 1989). The knowledge concerning their morphological features and habitat requirements is essential to decorate different types of gardens with 'ornamental grasses'.

The purpose of the studies was to evaluate growth and flowering of the species of 'ornamental grasses'. The research dealt with morphological characteristics - the clump diameters, the number of vegetative and generative culms - species and cultivars evaluated during the successive seasons. Aesthetic attributes were analysed as well. Changes in their scales during one vegetative seasons as well as in the course of successive years of cultivation have a significant impact on small compositions or a whole garden. Whithin this group of plants there are species and varieties which surpass others due to their invasive habits. On the other hand, this group of plants includes such grasses which hardly change their "living space". Consequently, it is vital to learn morphological features of these species which are becoming more and more commercially popular.

\section{MATERIALS AND METHODS}

The experimental material were species and cultivars as follows: Calamagrostis $x$ acutiflora 'Karl Foerster' (H a b e r, 1989), Deschampsia caespitosa 'Goldtau', Miscanthus sacchariflorus 'Robustus', Muehlenbergia mexicana (L.) Trin. (U r b a ń s k i, 2001), Phalaris arundinacea L. The plants came from the collection of ornamental grasses of the Institute of Ornamental Plants and Landscape Architecture of University of Life Science in Lublin. The experiment was set up in flat area on a sunny site in autumn 2003. Young clusters with the diameter $8-10 \mathrm{~cm}$ were planted in the plot 150 $\mathrm{cm}$ wide, in spacing of $35 \times 50 \mathrm{~cm}$. They were protected with a light layer of composted bark against winter weather. The grey and brown podzolic soil made of loess on chalky marls with $\mathrm{pH} 6.5$ constituted the ground. The observations conducted in the years 2004 and 2005, 
which means in the first and second vegetative season of investigated species, started on the $30^{\text {th }}$ of April and were continued till the end of September. On the $30^{\text {th }}$ of July 2004 and 2005 soil samples were taken for analyses from the plots where the grasses were grown. The content of available nutrients in the successive years were as follows: the year $2004-\mathrm{N}-\mathrm{NO}_{3}-20$, P-50, K-120, $\mathrm{Ca}-600$ and $\mathrm{Mg}-35 \mathrm{mg}$ in $1 \mathrm{dcm}^{-3}$ of soil, the year 2005 $-\mathrm{N}_{-} \mathrm{NO}_{3}-31, \mathrm{P}-60, \mathrm{~K}-170, \mathrm{Ca}-500$ and $\mathrm{Mg}-40 \mathrm{mg}$ in 1 $\mathrm{dcm}^{-3}$ of soil. In June and July the clumps were radically treated with $0,1 \%$ multicomponent dissolved liquid fertilizer INSOL U. Observations and measurements were conducted taking into consideration ten plants of each species and cultivars. The systematical measurements dealt with the height of the clustery - the measurement was made from the base of a plant to the end of leaves in their natural position; the number of vegetative culms and peduncles in one cluster; the length of peduncles and inflorescences. The diameter of each clump was measured in its widest place. Not only the term of the beginning and ending of flowering was noted down but the period of the most stunning beauty appeal of the investigated species and varieties. In the Spring 2004 frost resistance of the plants was assessed. The experiment was meant with 10 repetitions where one repetition dealt with one plant (one clump). The results of research were verified by using variance methods. The differences between means were evaluated by applying the Tukey test at $\mathrm{p}=0.05$.

During two periods: the middle of July and August beauty attributes of the grass species and cultivars under discussion were examined by three experts. The 5 stage scale was used to appreciate the plants. A species characterised by the best qualities reached the top in the rank by scoring 5 points. The features which were taken into consideration while estimating decorative values of the ornamental grasses were as follows: the architecture of plant, the colour of culms and leave blades, the size and colour of inflorescences as well as the duration of their remaining on a single plant.

\section{RESULTS AND DISCUSSION}

The main beauty attributes typical of 'ornamental grasses' are their shapes, sizes and ranges of colours of vegetative and generative peduncles ( $\mathrm{C}$ l a y t o $\mathrm{n}$ and Renvoize, 1986). Most of the species, especially medium and tall height provide a very strong vertical accent to any garden thanks to their stiff parallel or arched vegetative peduncles growing from dense clumps and supporting inflorescences. Culms are encircled with long linear leaves which gently hang down, form sharp folds in top parts or almost horizontally stick out from a clump (U r bańs k i, 1997; L e y h e, 2007). A lot of species of 'ornamental grasses' are highly frost resistant, however young grasses planted in autumn ought to be protected against severe winter temperatures ( $\mathrm{U} r$ b a ń s k i, 2001). In the Lublin region winter 2003/2004 was typical of this area. The average monthly air temperatures were not higher then in the previous years (means monthly air temperatures were: in November 2003: $1.3^{\circ} \mathrm{C}$, in December $2003: 1.3^{\circ} \mathrm{C}$, in January 2004: $-5.6^{\circ} \mathrm{C}$, in February 2004: $-1^{\circ} \mathrm{C}$ and in March 2004: $2.8^{\circ} \mathrm{C}$ ) so that snow layer in January and February provided a natural protection for the grasses planted in autumn. All specimen of examined plants were not affected by winter and started their vegetation in early spring. In the third decade of April three species started to grow: Calamagrostis $x$ acutiflora 'Karl Foerster', Deschampsia caespitosa 'Goldtau' and Phalaris arundinacea. Muehlenbergia mexicana began its growth ten days later followed by Miscanthus sacchariflorus 'Robustus' at the end of May (Tab. 1). The examined species and varieties were characterised by dynamic growth of their vegetative parts at the beginning of vegetation, however these qualities differ distinctively as for as each species is separately concerned. The intensive growth of Deschampsia caespitosa 'Goldtau' and Calamagrostis $\mathrm{x}$ acutiflora 'Karl Foerster' was observed from the $1^{\text {st }}$ decade of May till the $1^{\text {st }}$ decade of June, whereas Muhlenbergia mexicana was growing luxuriantly from the $1^{\text {st }}$ decade of May till the end of June. The lush growth of the surface part Phalaris arundinacea occurred from the middle of May until the middle of August. Miscanthus sacchariflorus showed the similar progress. The rate of growth of the flowering grasses slowed down shortly before their blooming.

The experiment reveals that Deschampsia caespitosa 'Goldtau', Muehlenbergia mexicana and Phalaris arundinacea, before inflorescences appearing, in the first year after being planted, reached the height 48, 68 and $60 \mathrm{~cm}$ respectively. Next year they became higher: 66, 70 and $84 \mathrm{~cm}$ (Tab. 2). The heighest 'ornamental grass' was Miscanthus sacchariflorus 'Robustus' reaching over $150 \mathrm{~cm}$. The second grass while considering its height, was Calamagrostis x acutiflora 'Karl Foerster', which in 2005 grew to $110 \mathrm{~cm}$ before flowering. Apart from height, while designing a flowerbed, the plant diameter is of significant importance ( $\mathrm{L}$ e y he, 2007; Urbański, 2001). This feature can change during a few successive vegetative seasons. According to the observations the species which chanced the size of its clump at the least dynamic rate throughout two years was Calamagrostis x acutiflora 'Karl Foerster'. In spite of a large number of linear vegetative culms (379-408) this grass was characterised by a dense clump whose diameter was up to $54 \mathrm{~cm}$ in the first year while in the second year it was up to $64 \mathrm{~cm}$. The soaring shape of Calamagrostis x acutiflora 'Karl Foerster' was also enhanced by a vertical, parallel arrangement of penducles reaching up to $190 \mathrm{~cm}$. The clump produced 


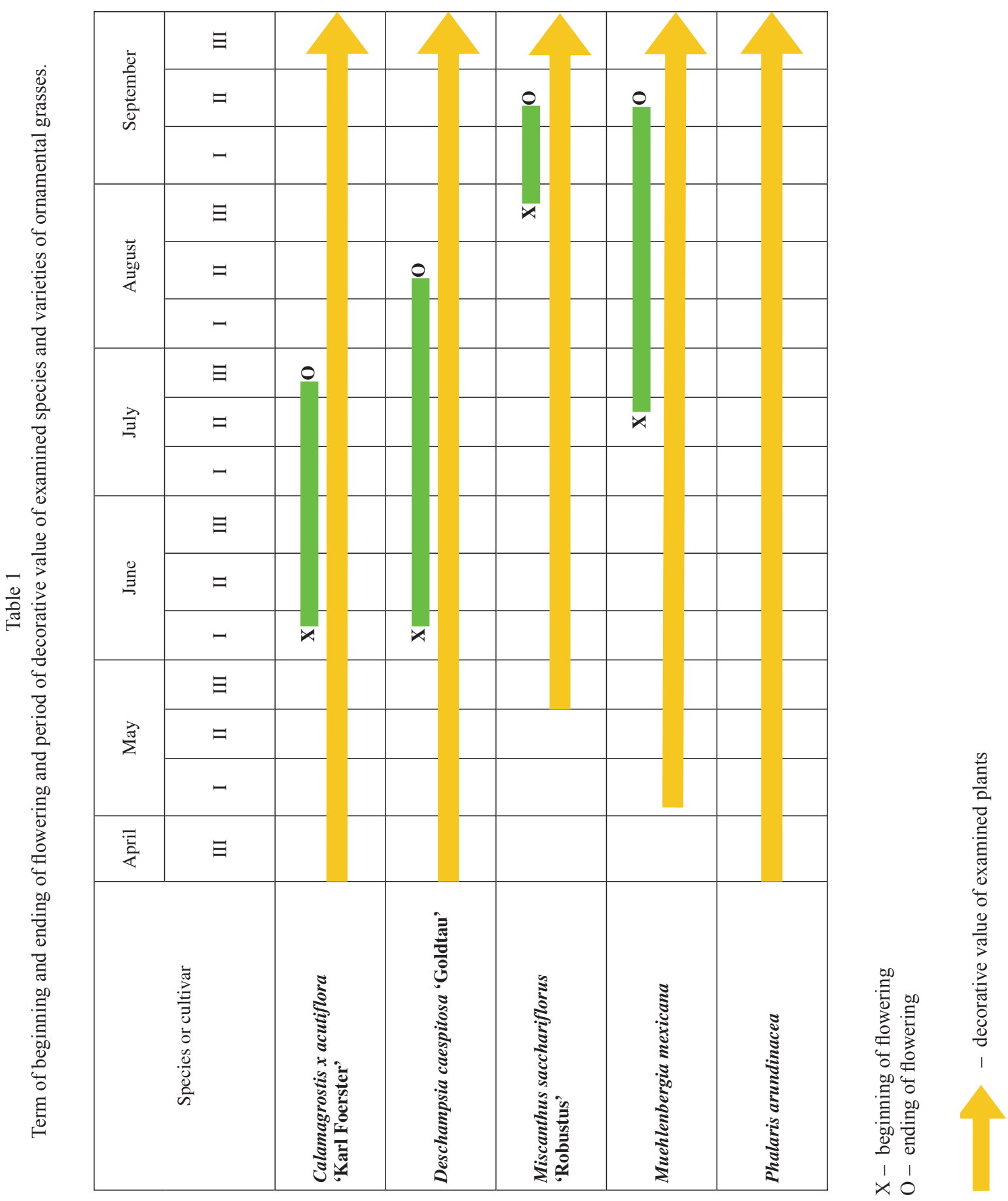


Table 2

Morphological features of 'ornamental grasses' in the first and second year of cultivation.

\begin{tabular}{|c|c|c|c|c|c|c|c|}
\hline Lp. & $\begin{array}{l}\text { Species and } \\
\text { cultivars }\end{array}$ & Years & $\begin{array}{l}\text { Height of } \\
\text { plants before } \\
\text { flowering } \\
(\mathrm{cm})\end{array}$ & $\begin{array}{l}\text { Plants } \\
\text { diameter } \\
(\mathrm{cm})\end{array}$ & $\begin{array}{l}\text { Number of } \\
\text { culms }\end{array}$ & $\begin{array}{r}\text { Asses } \\
\text { decorative } \\
\text { plants on } t \\
1 \text { to } \\
\text { June }\end{array}$ & $\begin{array}{l}\text { lent of } \\
\text { scale from } \\
\text { oints } \\
\text { August }\end{array}$ \\
\hline \multirow{2}{*}{1.} & \multirow{2}{*}{$\begin{array}{l}\text { Calamagrostis x acutiflora } \\
\text { 'Karl Foerster' }\end{array}$} & 2004 & $96 \mathrm{~b}$ & $54 \mathrm{~b}$ & $379 \mathrm{~b}$ & 5 & 5 \\
\hline & & 2005 & $110 \mathrm{a}$ & $64 \mathrm{a}$ & $408 \mathrm{a}$ & 4.6 & 5 \\
\hline \multirow{2}{*}{2.} & \multirow{2}{*}{$\begin{array}{l}\text { Deschampsia caespitosa } \\
\text { 'Goldtau' }\end{array}$} & 2004 & $48 \mathrm{~b}$ & $50 \mathrm{~b}$ & $386 \mathrm{~b}$ & 5 & 5 \\
\hline & & 2005 & $66 \mathrm{a}$ & $78 \mathrm{a}$ & $402 \mathrm{a}$ & 5 & 5 \\
\hline \multirow{2}{*}{3.} & \multirow{2}{*}{$\begin{array}{l}\text { Miscanthus } \\
\text { sacchariflorus 'Robustus' }\end{array}$} & 2004 & $150 \mathrm{a}$ & $44 \mathrm{~b}$ & $128 \mathrm{~b}$ & 4.6 & 5 \\
\hline & & 2005 & $152 \mathrm{a}$ & $97 \mathrm{a}$ & $135 \mathrm{a}$ & 4.8 & 5 \\
\hline \multirow{2}{*}{4.} & \multirow{2}{*}{$\begin{array}{l}\text { Muehlenbergia } \\
\text { mexicana }\end{array}$} & 2004 & $68 \mathrm{a}$ & $30 \mathrm{~b}$ & $266 \mathrm{~b}$ & 4.5 & 4.8 \\
\hline & & 2005 & $70 \mathrm{a}$ & $68 \mathrm{a}$ & $280 \mathrm{a}$ & 4.3 & 5 \\
\hline \multirow{2}{*}{5.} & \multirow{2}{*}{$\begin{array}{l}\text { Phalaris } \\
\text { arundinacea }\end{array}$} & 2004 & $60 \mathrm{~b}$ & $46 \mathrm{~b}$ & $408 \mathrm{~b}$ & 5 & 4.3 \\
\hline & & 2005 & $84 \mathrm{a}$ & $130 \mathrm{a}$ & $455 \mathrm{a}$ & 5 & 4 \\
\hline
\end{tabular}

Means with the same letter do not differ significantly (Tukey test, $\mathrm{p}=0.05$ ).

Table 3

Chosen morphological features of inflorescences of examined 'ornamental grasses' species in the first and second year of cultivation.

\begin{tabular}{|c|c|c|c|c|c|}
\hline Lp. & $\begin{array}{l}\text { Species and } \\
\text { cultivars }\end{array}$ & Years & $\begin{array}{l}\text { Number of } \\
\text { peduncle }\end{array}$ & $\begin{array}{c}\text { Length of } \\
\text { peduncle }(\mathrm{cm})\end{array}$ & $\begin{array}{l}\text { Length of } \\
\text { inflorescence } \\
(\mathrm{cm})\end{array}$ \\
\hline \multirow{2}{*}{1.} & \multirow{2}{*}{$\begin{array}{l}\text { Calamagrostis } x \text { acutiflora } \\
\text { 'Karl Foerster' }\end{array}$} & 2004 & $29 \mathrm{a}$ & $183 \mathrm{~b}$ & $29 \mathrm{~b}$ \\
\hline & & 2005 & $30 \mathrm{a}$ & $190 \mathrm{a}$ & $34 \mathrm{a}$ \\
\hline \multirow{2}{*}{2.} & \multirow{2}{*}{$\begin{array}{l}\text { Deschampsia caespitosa } \\
\text { 'Goldtau' }\end{array}$} & 2004 & $122 \mathrm{a}$ & $117 \mathrm{a}$ & $32 \mathrm{a}$ \\
\hline & & 2005 & $128 \mathrm{a}$ & $120 \mathrm{a}$ & $34 \mathrm{a}$ \\
\hline \multirow{2}{*}{3.} & \multirow{2}{*}{$\begin{array}{l}\text { Miscanthus } \\
\text { sacchariflorus 'Robustus' }\end{array}$} & 2004 & $19 \mathrm{~b}$ & 202 a & $24,5 \mathrm{a}$ \\
\hline & & 2005 & $38 \mathrm{a}$ & $197 \mathrm{~b}$ & $24 \mathrm{a}$ \\
\hline \multirow{2}{*}{4.} & \multirow{2}{*}{$\begin{array}{l}\text { Muehlenbergia } \\
\text { mexicana }\end{array}$} & 2004 & $212 \mathrm{a}$ & $78 \mathrm{~b}$ & $12 \mathrm{a}$ \\
\hline & & 2005 & $200 \mathrm{~b}$ & $82 \mathrm{a}$ & $12,5 \mathrm{a}$ \\
\hline
\end{tabular}

Means with the same letter do not differ significantly (Tukey test, $\mathrm{p}=0.05$ ). 
approximately 29-30 peduncles (tab.3). A slightly larger diameter during two years of cultivation was observed in two other species - Deschampsia caespitosa 'Goldtau' and Muehlenbergia mexicana. In spring they formed regular clumps of dark green leaves while Deschampsia caespitosa 'Goldtau' produced shiny blades. On the other hand, Muehlenberia mexicana had matt leaves and there were 386-402 and 266-280 blades leaves respectively. In the second year of cultivation the diameter of Deschampsia caespitosa 'Goldtau' clumps increased by $56 \%$ and of Muehlenbergia mexicana by $120 \%$ in comparison with the first year. These two species also produced a large number of peduncles throughout their flowering seasons. From the clump of Deschampsia caespitosa 122-128 (Tab. 3) thin and stiff peduncles emerged. They were ended with large open wisps which formed huge bright sweeping clouds of flowers above leaves. Muehlenbergia mexicana created 200-212 peduncles ended with wisps hanging off the outside of the clump, which were brown and cropper in autumn The most expansive species appeared to be Miscanthus sacchariflorus 'Robustus' and Phalaris arundinacea. The increase of clumps diameter in these plants over the course of cultivation in 2005 was doubled or even tripled in comparison to the first year of experiment.

Miscanthus sacchariflorus 'Robustus' is a high grass which reached almost $2 \mathrm{~m}$ during its flowering season. The two year old clump consisted approximately of 135 vegetative peduncles with characteristic linear blades bending gently outside. The plant created huge vertical form which resembled 'fountaines' in their shapes. Its most stuming decorative features are soft, silky inflorescences set on stiff straight peduncles dominating high above the clump. Miscanthus sacchariflorus 'Robustus' produced 19 inflorescences in the first year of the experiment while in the second one this number was doubled. Among the examined plants Miscanthus sacchariflorus bloomed as the last at the end of August and produced new peduncles till the middle of September (Tab. 1). Phalaris arundinacea, the grass of middle height, is valued for its wide blades with the white strap along every leaf, which seems to be its most ornamental quality. This species expanded increasingly, so that in the second year of cultivation it produced $20 \%$ more vegetative culms than in the first year (408-455 leaves). At the same time its tendency for lodging was observed during heavy rain falls.

Taking into consideration the decorative qualites observed in June Deschampsia caespitosa, Calamagrostis x acutiflora 'Karl Foerster', Miscanthus sacchariflorus 'Robustus' and Phalaris arundinacea enjoyed the experts' highest appreciation (Tab. 2). A great attention was paid to such characteristics as bright green foliage, the scale of the plants as well as a great number of light inflorescences created by Deschampsia caespitosa. Du- ring autumn all the grasses under discussion except for Phalaris arundinacea won the highest places in the rank - 5 points. The plants investigated in this experiment due to their beauty appeal can enrich various garden compositions. Some of them like Miscanthus sacchariflorus or Deschampsia caespitosa 'Goldtau' create a strong visual accent in every park or garden (U r b a ń s k i , 1996, 1997, 2001). It is advisable to plant Miscanthus sacchariflorus 'Robustus' separately or in small groups in large spatial flowerbeds or naturalistic gardens. Others species like soaring Calamagrostis x acutiflora 'Karl Foerster', ethereal Deschampsia caespitosa 'Goldtau' or green and rust Muehlenbergia mexicana should be combined with perennials with large leaves and distinctive colours. Most the examined grasses change the size of their clumps significantly in the course of the growing season. In addition, these grasses enlarge their size while blooming. These characteristics should not be neglected especially when they are meant to grow close to smaller species. The ornamental grasses investigated in this experiment throughout the whole vegetative season from the moment of full foliage development until the edn of flowering not only create marvelous decorative forms but retain their characteristic shapes and forms. What is more, they enhance garden beauty even during winter.

\section{CONCLUSIONS}

1. The young plant sof the five species of 'ornamental grasses' always survive Winter perfectly in the east of Poland.

2. Among the investigated of 'ornamental grasses' Calamagrostis $\mathrm{x}$ acutiflora 'Karl Foerster' change the size of its clump at the lowest speed throughout two years of cultivation. While Muehlenbergia mexicana and Phalaris arundinacea belong to species which appear to be very expansive - they increase their clump diameters 2-3-times during one vegetative season.

3. Grasses which demonstrate green leaves at the earliest time - the third decade of April - are Calamagrostis $\mathrm{x}$ acutiflora 'Karl Foerster', Deschampsia caespitosa 'Goldtau' and Phalaris arundinacea. On the other hand, the leaves of Calamagrostis $\mathrm{x}$ acutiflora 'Karl Foerster' and Miscanthus sacchariflorus change the range of their colours at the end of the vegetative season.

4. Especially decorative inflorescences staying on single plant also during winter period are developed by $D e$ schampsia caespitosa 'Goldtau', Miscanthus sacchariflorus 'Robustus' and Muehlenbergia mexicana. 


\section{REFERENCES}

Clayton W. D., Renvoize S. A., 1986. Genera graminium. Grasses of the world. Kew Bulletin Additional Series 13: 1-389.

Falkowski M. (red.), 1982. Trawy polskie. PWRiL. Warszawa.

Frey L., 1997. Nowe dla nauki rodzaje i gatunki traw opisane w latach 1991-1995. / Genera and species of grasses new of science desecribet in 1991-1995. Wiadomości Botaniczne, 41: 19-26.

Haber Z., 1989. Trawy rabatowe dla naszych parków i ogrodów. Oficyna Wydawnicza ATENA. Poznań.

Leyhe U., 2007. Trawy i paprocie. MUZA, Świat Książki.

Mizianty M., 1995. Trawy - grupa roślin, która odniosła ewolucyjny sukces. / Grasses - group of plants which achieved ewolutional succes. Wiadomości Botaniczne, 39 $(1,2)$ : 59-70.

Urbański P., 1996. Walory dekoracyjne traw ozdobnych z rodzaju Deschampsia i Sesleria. / Decorative value of ornamental grasses from Deschampsia and Sesleria. Rocz. AR Poznań, 288 (24): 61-67.

Urbański P., 1997. Trawy rabatowe - przyszłościowy element roślinności dla terenów zieleni. / Ornamental grasses the future element of plants for landscape arrangements. Materiały Międzynarodowej Konferencji Naukowej „Sztuka ogrodów w krajobrazie miasta”. Wrocław, 20-22 czerwiec 1997: 183-188.

Urbański P., 2001. Trawy ozdobne, turzyce i sity. PWRiL, Poznań.

\section{Ocena wzrostu i kwitnienia wybranych gatunków traw ozdobnych w rejonie Lublina}

\section{Streszczenie}

Duża wartość dekoracyjna (kształt i wielkość kwiatostanów, kolorystyka i tekstura liści, zróżnicowana intensywność wzrostu), a także znaczna tolerancja co do warunków siedliskowych, stosunkowo niewielka podatność na choroby oraz mała wrażliwość na szkodniki sprzyja rozpowszechnianiu 'traw ozdobnych' w różnych ogrodach i przestrzeniach miejskich. $Z$ pięciu badanych gatunków i odmian wszystkie można polecić do nasadzeń w chłodniejszym rejonie wschodniej Polski. Gatunkami najwcześniej rozpoczynającymi wegetację i kwitnienie były Calamagrostis x acutiflora 'Karl Foerster' oraz Deschampsia caespitosa 'Goldtau'. Te gatunki, najlepiej sadzone pojedynczo lub w małych grupach, można również polecić do małych założeń ogrodowych. Na duże powierzchnie, do ogrodów naturalistycznych czy też jako rośliny strukturalne rabat, nadają się Calamagrostis $x$ acutiflora 'Karl Foerster', Deschampsia caespitosa 'Goldtau' oraz Miscanthus sacchariflorus 'Robustus'. Typowo okrywową trawą, ozdobną z liści jest Phalaris arundinacea $\mathrm{L}$. 